\title{
四輪操舵車の安定性に関する一考察
}

\author{
自動車を操舵トルク入力系と見る場合— \\ 藤 代 武 史 ${ }^{*}$. 伊 藤健* $-川$ 辺 武 俊* \\ 金 井 喜美雄 ${ }^{* *}$. 越 智 徳 昌**
}

\section{A Study on the Stability of a Four Wheel Steering Vehicle As a Steering Torque Input System}

Takeshi Fujishiro*, Ken Ito*, Taketoshi Kawabe*

Kimio Kanar** and Yoshimasa OchI**

We have already proposed a feedforward type control system for the four wheel steering (4 WS) vehicle using the model following control theory. The control system is designed on the assumption that the input is the steering wheel angle. In this paper we deal with the stability of the $4 \mathrm{WS}$ vehicle. Generally, it is considered that the driver steers a vehicle by both steering wheel angle and steering wheel torque. We carry out an investigation of the pole location and a computer simulation for the $4 \mathrm{WS}$ vehicle as a steering wheel torque input system that has a feedback path to the control system through the dynamics of a steering system. Furthermore, proving ground tests are conducted with a real $4 \mathrm{WS}$ vehicle. The results show that the feedforward control system has an effectiveness to stabilize the vehicle motion.

Key Words: vehicle control, four wheel steering vehicle, feedforward control, stability

\section{1. まえがき}

最近自動車の操縦性や安定性に対する要求が高く, これを満たす方法の一つとして前輪のみならず後輪を あ皘極的に操舵する四輪操舵の研究が盛んに行われ， 一部実用化されている. 方式としては操舵角入力に対 してフィードフォワード補償のみで後輪むしくは前後

†第 30 回自動制御連合講演会で一部発表 $($ 昭 $62 \cdot 10)$

* 日産自動車 (株) 中央研究所 横須賀市夏島町 1

** 防衛大学校 横須賀市走水 1-10-20

* Central Engineering Labolatories, Nissan Motor Co. LTD., Yokosuka

** The National Defense Academy, Yokosuka (Received June 25, 1988) (Revised October 6, 1988)
輪を操舵するすの㐱5)や，自動車のヨーレートや横滑 り角などの検出を前提としてフィードバック補償を加 えたすの ${ }^{6), 7)}$ ，などが提案されている。

ここでは四輪操舵車の安定性を扱うが，自動車の安 定性は，ドライバを含めて人間-自動車系として捉え る場合と自動車固有の安定性として捉える場合とが ある。

四輪操舵車の人間-自動車系としての安定性につい て解析的に研究したものとして, 林ら ${ }^{81}$ の報告があり， フィードフォワード補償あるいはフィードバック補償 で後輪を操舵する四輪操舵車で, 從来の前輪操舵車よ りあ極配置が好ましくなることが示されている.

一方, Good が示すように ${ }^{91}$ ，ドライバは主に操舵 角で操舵する場合と，主に操舵トルクで操舵する場合 とがあるので, 自動車固有の安定性についても同様に 操舵角を入力とする場合に加えて，操舵トルクを入 力とする場合をむ考慮するととが重要であると考えら れる。

四輪操舵車を操舵角入力系として見る場合の安定性 については, 井口7), 永井ら ${ }^{6}$, 入江 $~^{10)}$ が状態量をつ ィードバックすることで安定性の向上が図られること を示している.

操舵トルクを入力とする場合については，操舵角入 力に対しフィードフォワード補償のみで後输を操舵す る四輪操舵車において, 前輪操舵車に比べ安定性の向 上がみられるととを筆者らが実験的に示唆している.

本論文では筆者らがすでに提案した四輪操舵車の制 御方式を中心に，自動車固有の安定性について考察す る.

自動車の操舵入力を操舵角と考えると，乙こで取り 上げる方式は，操舵角に対しフィードフォワード補償 
のみで後輪を操舵する方式であるため，その制御系は 自動車系の極配置には関与しない。しかし操舵入力を 操舵トルクとすると自動車の運動がステアリング系を 通して操舵角にフィードバックされ，極配置住影響す るととが考えられる．そこでまず操舵トルクを入力と した四輪操舵車の物理モデルをつくる. 四輪操舵の制 御則としては，1)操舵角に対し後輪を比例的に操舵す る比例制御則，2)モデル適合により，操舵角に対しヨ ーレートの所望の応答を得るョーレート制御則，3）ヨ ーレートと横加速度の線形結合である $D *$ *操舵角に 対し所望の応答とする $D *$ 制御則，4)モデル追従によ り操舵角に対し横加速度の所望の応答を得る横加速度 制御則，の四つをとりあげる.つぎにそのおのおのの 極配置を調べ「舵手放し安定性試験」の計算機シミュ レーションを行い時間領域応答を調べる。ささろに四輪 操舵車を試作し，「舵手放し安定性試験」と「横風安 定性試験」の車両実験を実施し, その結果之計算機シ ミュレーションの結果とを比較する.

\section{2. 四輪操舵車の記述}

本論文に扔いて取り扱う操舵トルクを入力とした四 輪操舵車の構成を Fig. 1 亿示す. 操舵角之後輪舵角 とを入力とした車両の平面運動の方程式, 車両のステ アリング系の運動方程式，およびコントローラの状態 方程式の三つを連立させ, 操舵トルクを入力とした四 輪操舵車の状態方程式を作る.

後輪操舵機構を有する車両のヨーと横の二自由度平 面運動に関する状態方程式は，つぎのように表わすと とができる.

$$
\dot{X}_{p}=A_{P} X_{p}+B_{P} \delta_{R}+B_{P F} \theta
$$

ここで,

$$
\begin{aligned}
& X_{p}^{T}=\left[\begin{array}{lll}
\dot{\psi} & V_{Y}
\end{array}\right]
\end{aligned}
$$

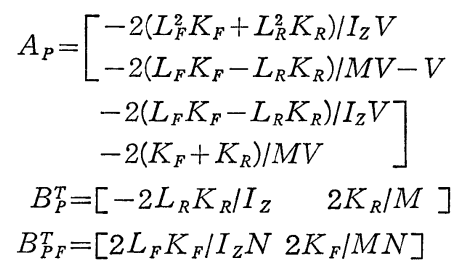

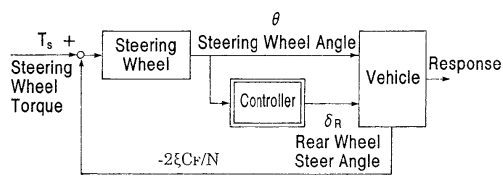

CF : Cornering Force of Front Tires

Fig. 1 Block diagram of $4 \mathrm{WS}$ vehicle for torque input
であり， $\dot{\phi}$ はョーレート， $V_{Y}$ は横方向速度， $\delta_{R}$ は後 輪実舵角， $\theta$ は操舵角， $V$ は車速， $M$ は質量， $I_{Z}$ は $\exists$ 一慣性モーメント， $L_{F}$ は前輪・重心点距離， $L_{R}$ は 後輪・重心点距離, $K_{F}$ は前輪等価コーナリングパワ 一, $K_{R}$ は後輪コーナリングパワー $N$ はステアリン グギア比である.

キングピン回りの慣性，および粘性は十分小さいと 仮定し，ステアリング系の剛性は，等価コーナリング パワーを用いることで表わすと，ステアリング系の状 態方程式はつぎのように表わすととができる.

$$
\dot{X}_{s}=A_{S} X_{s}+B_{S 1} T_{S}+B_{S 2} X_{p}
$$

ここで,

$$
\begin{aligned}
X_{s}^{T} & =\left[\begin{array}{ll}
\dot{\theta} & \theta
\end{array}\right] \\
A_{S} & =\left[\begin{array}{cc}
-D_{S} / I_{S} & -2 \xi K_{F} / N^{2} I_{s} \\
1 & 0
\end{array}\right] \\
B_{S 1}^{T} & =\left[\begin{array}{ll}
1 / I_{S} & 0
\end{array}\right] \\
B_{S 2} & =\left[\begin{array}{cc}
2 \xi L_{F} K_{F} / N I_{S} V & 2 \xi K_{F} / N I_{S} V \\
0 & 0
\end{array}\right]
\end{aligned}
$$

であり, $T_{S}$ は操舵トルク， $D_{S}$ は粘性， $I_{S}$ はステア リングホイール慣性モーメント，乡はトレール長であ る.

つぎにコントローラの状態方程式と出力方程式とを 次式のように招く.

$$
\begin{aligned}
\dot{X}_{c} & =A_{C} X_{c}+B_{C} \theta \\
\delta_{R} & =C_{C} X_{c}+D_{C} \theta
\end{aligned}
$$

以上より操舵卜ルク入力四輪操舵車両の状態方程式 は,

$$
\dot{X}=A X+B T_{S}
$$

ただし，

$$
X^{T}=\left[\begin{array}{lll}
X_{p}^{T} & X_{c}^{T} & X_{s}^{T}
\end{array}\right]
$$

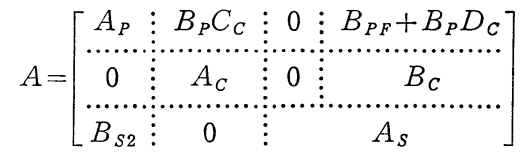

$$
B^{T}=\left[0|0| B_{S 1}^{T}\right]
$$

である，乙こで，状態量 $\dot{\phi}, V_{Y}$ がステアリング系を 通してコントローラにフィードバックされることに注 意すべきである． $A$ 行列のなかにコントローラの行列 $A_{C}, B_{C}, C_{C}, D_{C}$ が現われており，乙れらが極配置 影響することがわかる.

おの㧍のの制御則についてコントローラの状態方程 式を示す.

（1）比例制御則

コントローラはダイナミクスをあたず,

$$
\begin{aligned}
& A_{C}=0, B_{C}=0, C_{C}=0, \\
& D_{C}=\text { (定数) }
\end{aligned}
$$


である．理想的な $D_{C}$ の值を選べば，定常的な横滑り 角 $\tan ^{-1}\left(V_{Y} / V\right)$ を 0 にできる.

(2) ヨーレート制御則

ヨーレートを規範モデルの応答に適合させるヨーレ ート制御則では規範モデルを 1 次として,

$$
\begin{aligned}
& \dot{X}_{r}=a_{R} X_{r}+b_{R} \theta \\
& Y_{r}=c_{R} X_{r}
\end{aligned}
$$

とおくとコントローラは 2 次となり ${ }^{11)}, c_{R}=1$ とする と， $X_{C}, A_{C}, B_{C}, C_{C}, D_{C}$ は，つぎのように表わせ る.

$$
\begin{aligned}
& X_{C}=\left[\begin{array}{ll}
X_{c 1} & X_{c 2}
\end{array}\right], X_{c 1}=X_{r} \\
& a_{C 11}=a_{R}, a_{C 12}=0 \\
& a_{C 21}=\left(b_{P 12} a_{P 21}+b_{P 22} a_{R}-b_{P 22} a_{P 11}\right) / b_{P 12} \\
& a_{C 22}=\left(b_{P 12} a_{P 22}-a_{P 12} b_{P 22}\right) / b_{P 12} \\
& B_{C}^{T}=\left[b_{R}\left(b_{P 21} b_{P 12}+b_{P 22} b_{R}-b_{P 22} b_{P 11}\right) / b_{P 12}\right] \\
& C_{C}=\left[\left(a_{R}-a_{P 11}\right) / b_{P 12}-a_{P 12} / b_{P 12}\right] \\
& D_{C}=\left(b_{R}-b_{P 11}\right) / b_{P 12}
\end{aligned}
$$

ただし， $a_{C i j}, a_{P i j}, b_{P i j}$ はそれぞれ $A_{C}, A_{P}, B_{P}^{\prime}=$ $\left[\begin{array}{ll}B_{P F} & B_{P}\end{array}\right]$ の $i$ 行 $j$ 列の要素である.

(3) $D *$ 制御則 ${ }^{5)}$

ブロック図を Fig. 2 に示す. D*をヨーレートと 横加速度の線形結合

$$
D^{*}=D \alpha+(1-D) V \dot{\phi} \quad 0 \leqq D \leqq 1
$$

と定義すると $D^{*}$ のコントローラで発生される值 $\hat{D}^{*}$ の出力方程式は以下のように表わされる.

$$
\hat{D}^{*}=C_{P} \hat{X}_{p}+D_{P} \delta_{R}+D_{P F} \theta
$$

ここで

$$
\begin{aligned}
C_{P} & =\left[\begin{array}{ll}
D a_{P 21}+V & D a_{P 22}
\end{array}\right] \\
D_{P} & =D b_{P 22}, \quad D_{P F}=D b_{P 21}
\end{aligned}
$$

$\hat{X}_{p}$ は $X_{p}$ のコントローラで発生される值である. 規 範モデルの出力と $\hat{D} *$ との誤差を,

$$
\hat{e}=\hat{D}^{*}-Y_{R}
$$

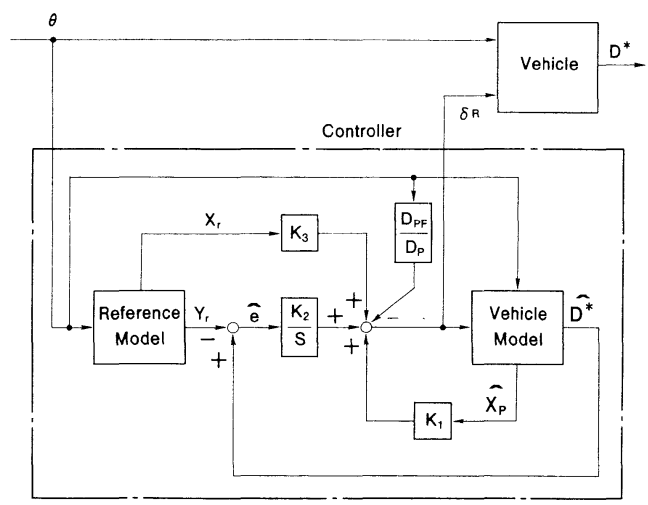

Fig. $2 D^{*}$-model following control system
と定義し規範モデルの入力 $\theta$ をステップと仮定すると 以下の拡大系を得る。

$$
\frac{d}{d t}\left[\begin{array}{c}
\dot{\hat{X}}_{p} \\
\hat{e} \\
\dot{X}_{r}
\end{array}\right]=\left[\begin{array}{ccc}
A_{P} & 0 & 0 \\
C_{P} & 0 & -c_{R} \\
0 & 0 & a_{R}
\end{array}\right]\left[\begin{array}{c}
\dot{\hat{X}}_{p} \\
\hat{e} \\
\dot{X}_{r}
\end{array}\right]+\left[\begin{array}{c}
B_{P} \\
D_{P} \\
0
\end{array}\right] \dot{\delta}_{R}
$$

後輪舵角の制御則を,

$$
\delta_{R}=K_{1} \hat{X}_{p}+K_{2} \int_{0}^{t} \hat{e} d t+K_{3} X_{r}-D_{P F} / D_{p} \theta
$$

とすると $K_{1}, K_{2}, K_{3}$ はつぎの評価関数 $J$ を最小に する最適制御ゲインとしてリカッチ方程式を解くこと によって求めるてとができる.

$$
J=\int_{0}^{\infty}\left(Q \hat{e}^{2}+R \dot{\delta}_{R}^{2}\right) d t \quad Q \geqq 0, \quad R>0
$$

ここで $Q ， R$ は重みである.

このとき，(3), (4)式のコントローラの状態量お よび係数は以下のようになる.

$$
\begin{aligned}
X_{c}^{T} & =\left[\begin{array}{lll}
\hat{X}_{p}^{T} & \int_{0}^{t} \hat{e} d t & X_{r}
\end{array}\right] \\
A_{c} & =\left[\begin{array}{ccc}
A_{P} & 0 & 0 \\
C_{P} & 0 & -c_{R} \\
0 & 0 & a_{R}
\end{array}\right]+B_{R} C_{C} \\
B_{c}^{T} & =\left[\begin{array}{llll}
b_{P 11}-b_{P 12} \cdot b_{P 21} / b_{P 22} & 0 & 0 & b_{R}
\end{array}\right] \\
C_{C} & =\left[\begin{array}{lll}
K_{1} & K_{2} & K_{3}
\end{array}\right] \\
D_{C} & =-b_{P 21} / b_{P 22}
\end{aligned}
$$

ただし，

$$
B_{R}^{T}=\left[\begin{array}{llll}
b_{P 12} & b_{P 22} & D b_{P 22} & 0
\end{array}\right]
$$

(4) 横加速度制御則 ${ }^{5}$

$D^{*}$ 制御則において $D=1$ とおくと横加速度制御則 が得られる。

すでに実用化されている比例制御方式と比べ，以上 に示した筆者らの提案する方式は操舵角に対し後輪を 動的に操舵する, すなわち過渡特性を考慮しているこ とが一つの特徵である.

\section{3. 極配置の計算および計算機

$$
\text { シミュレーション }
$$

車両実験に用いる四輪操舵車の諸元は,

$$
\begin{aligned}
K_{F} & =45,372.92 \mathrm{~N} / \mathrm{rad} \\
K_{R} & =74,405.52 \mathrm{~N} / \mathrm{rad} \\
L_{F} & =1.122 \mathrm{~m}, L_{R}=1.428 \mathrm{~m} \\
M & =1,507 \mathrm{~kg} \\
I_{Z} & =2,205 \mathrm{Nms}^{2} \\
N & =17.6, D_{S}=0.588 \mathrm{Nms} \\
I_{S} & =0.061985 \mathrm{Nms}^{2} \\
\xi & =0.031 \mathrm{~m}
\end{aligned}
$$

である． $D_{S}$ には摩擦を等価的に粘性に置き換えて含 
ませた。

基本となる前輪操舵車（以下 $2 \mathrm{WS}$ と略）の操舵角 に対するヨーレート定常ゲインは

$$
G_{0}=V / 44.9\left(1+0.0019 V^{2}\right)
$$

であり，乙れに対し比例制御（以下 prop. と略）の定 数 $D_{C}$ は操舵角に対するョーレート定常ゲインGが,

$$
G=V / 35.7\left(1+0.0031 V^{2}\right)
$$

となるように決めた。 また以下の制御則ではョーレー ト定常ゲインが $G_{0}$ または $G$ である 2 通りの規範モ デルを用いた。

ヨーレート制御 1 (以下 $\dot{\phi} \operatorname{cnt} 1$ と略) の規範モデ ル伝達特性は,

$$
Y_{r} / \theta=G /(1+0.05 s)
$$

ヨーレート制御 2 (以下 $\dot{\phi} \operatorname{cnt} 2$ と略) の規範モデ ル伝達特性は,

$$
Y_{r} / \theta=G_{0} /(1+0.05 s)
$$

$D^{*}$ 制御 1 (以下 $D^{*} \operatorname{cnt} 1$ と略) は,

$$
Y_{r} / \theta=G V /(1+0.077 s)
$$

$D^{*}$ 制御 2 (以下 $D^{*} \operatorname{cnt} 2$ と略) は,

$$
Y_{r} / \theta=G_{0} V /(1+0.077 s)
$$

横加速度制御 1 (以下 $\alpha \operatorname{cnt} 1$ と略）は,

$$
Y_{r} / \theta=G V /(1+0.1 s)
$$

横加速度制御 2 (以下 $\alpha \mathrm{cnt} 2$ と略) は,

$$
Y_{r} / \theta=G_{0} V /(1+0.1 s)
$$

である.乙こで $s$ は微分演算子である.

また評価関数 (14)における重み $Q ， R$ は

$$
Q=1.0, \quad R=1.0
$$

としてある.

本研究でとりあげた閉ループの極を計算すると極の 数は, 前輪操舵車で 4 個, 比例制御則を用いた場合 4 個，ヨーレート制御則を用いた場合 6 個， D* 制御則 と横加速度制御則を用いた場合 8 個である. そのうち で自動車の運動に影響の大きいと考えられる共役な極 の 1 個を Fig. 3 a , bに示す.

Fig. $3 \mathrm{a}, \mathrm{b}$ から時速 $180 \mathrm{~km} / \mathrm{h}$ 付近で前輪操舵車 の極は安定限界に近づいているが，乙れに比べ四輪操 舵車の極は実軸からの距離が大きいととがわかる。ま た筆者らの制御則を用いると, 車速による極の移動が 少なくなりロバストであることがわかる。

Fig. $3 \mathrm{~b}$ から，筆者らの提案した後輪を動的に操舵 する万式は, 前輪操舵車と同じ定常ョーレートゲイン をあちながら，安定性を向上させるととがわかる．ま たFig. 3a から比例制御と同じ定常ヨーレートゲイン とした場合も，比例制御に比較し筆者らの方式は安定 性の寄与度が大きいととがわかる。

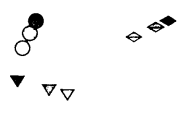

$\Delta$
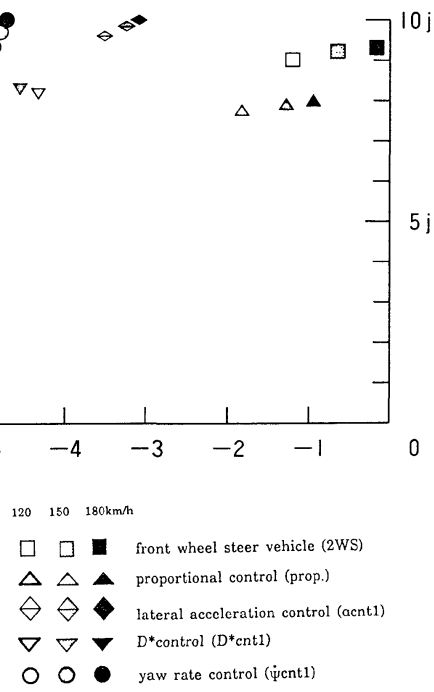

(a)

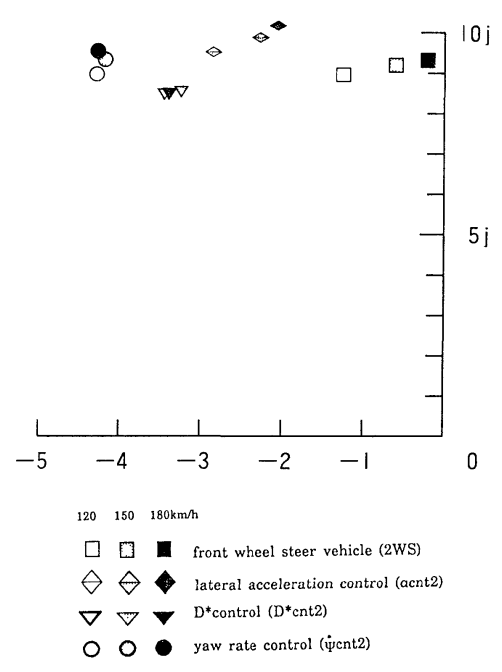

(b)

Fig. 3 Pole location

Fig. 4 にてれらのモデルの「舵手放し安定性試験」 のシミュレーション結果を示す.との試験は車両の自 由応答特性を評価するすのであり, 直進している状態 に操舵角によって初期值を与えてからステアリング八 ンドルを解放し車両の運動の収束性を調べるものであ る. 後述する車両実験と条件を揃えるため, 車速は $150 \mathrm{~km} / \mathrm{h}$, 初期の操舵角の入力パターンは,

$$
\theta(t)=\left[\omega^{2} /(s+\omega)^{2}\right] u(t)
$$

ただし $u(t)=70 \mathrm{deg}, \omega=2 \pi \cdot 4, \quad \theta(0)=0$ とし， $\theta(t)=57 \mathrm{deg}$ でステアリングを解放するようにした.

Fig. 4 と Fig. $3 \mathrm{a}$ とを比べると主要な極が虚軸か 

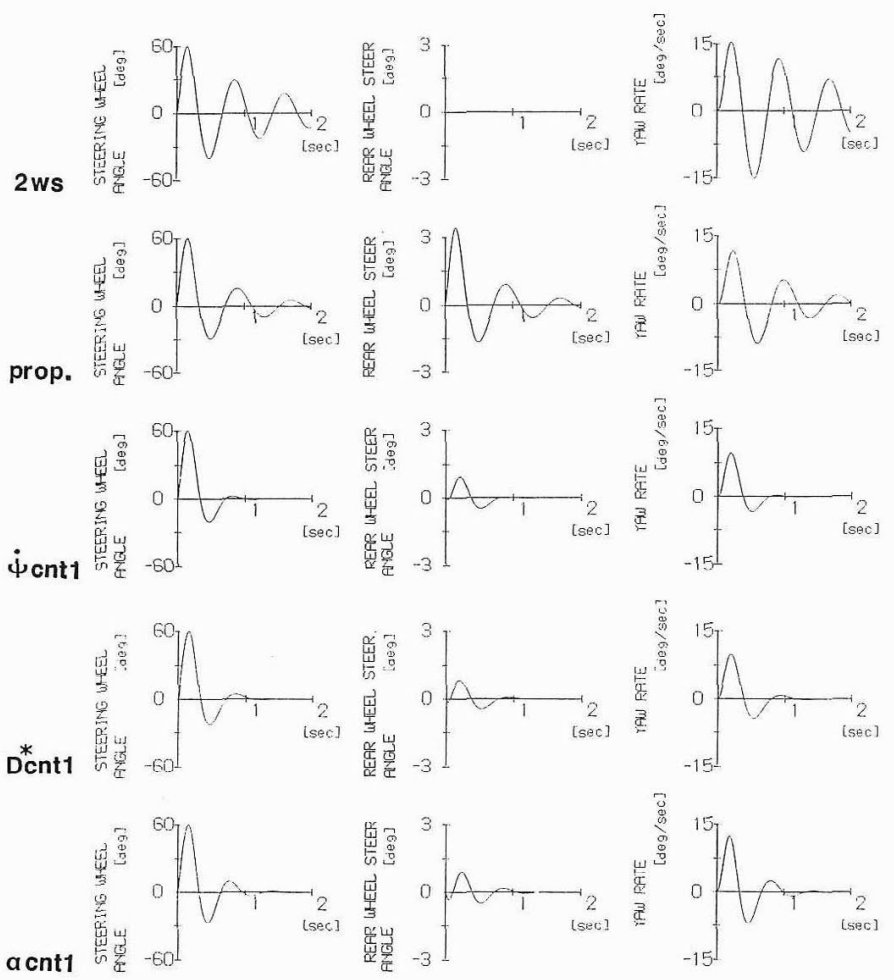

Fig. 4 Free response at $150 \mathrm{~km} / \mathrm{h}$ (simulation)
油圧サーボ機構をむち，後輪は車載さ れたマイクロコンピュータの指令によ って操舵される (Fig. 5, Photo. 2). マイクロコンピュータには拈のおのの 制御則がプログラミングされて抮り $2 \mathrm{~ms}$ ごこに後輸の操舵角が演算され る. 前輪操舵車の特性は後輪舵角学 に零に固定して実現する．四輸操舵車 の車両諸元は 3 章に示したとおりであ る。

Fig. 6 亿「舵手放し安定性試験」 の結果を示す，車速はシミュレーショ ンと同じ $150 \mathrm{~km} / \mathrm{h}$ とした. シミュレ ーション結果との一致は比較的良好 で，モデルは実際の車両の特性を本質 的には十分に表わしているということ がでさる、シミュレーション結果との 緭かい不一致はモデルを次数の低い簡 単なあのとしたとと，また実験では初 期の操舵角入力を完全に揃えるととが できないとと、などの理宙によると考 えられる。

Fig. 7 にヨーレート制御則の四輪
ら遠いほど運動の収束がよく，主要な極の位置と運動 の収束のようすは刘応していることが確かめられる。

ヨーレート制御, $D^{*}$ 制御, 横加速度制御では, 後 輸舵角が操舵角に対し当初逆相になる点や，遲れてピ ークを示す点などに捘輸定操舵角に対し動的に操舵す る特徴か現われて和り，比例制御と此べるとより少な い後輪の操舵量でより速やかなヨーレートの収束が得 られているととがわかる。

\section{4. 車両実 験}

つぎに四輸操舵車を用いたテストコース上での車両 実験を行った．との四輸操舵車（Photo. 1) は後輪に

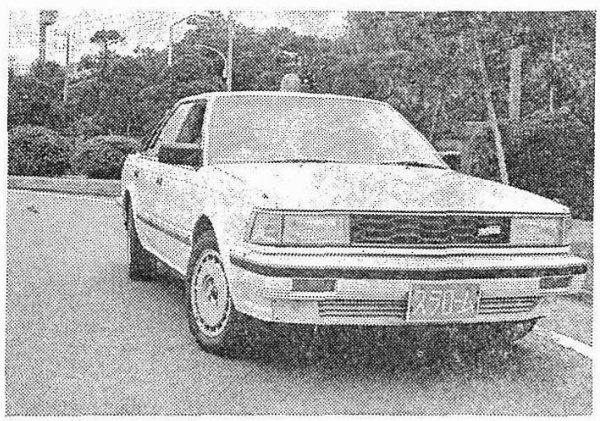

Photo. $14 \mathrm{WS}$ vehicle

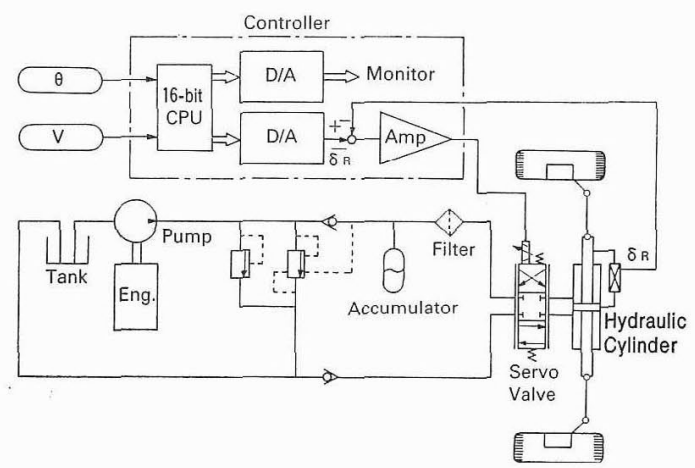

Fig. 5 Configuration of rear wheel steer angle control system

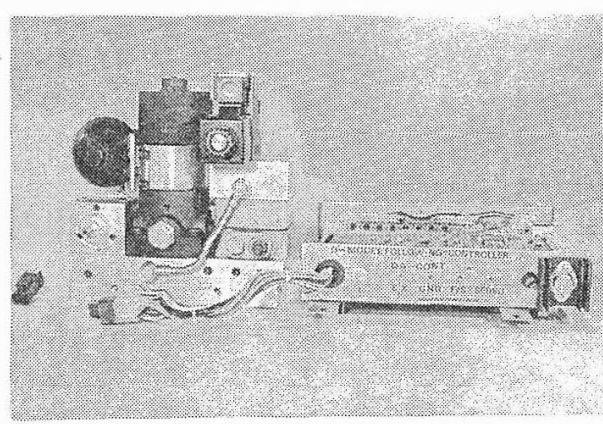

Photo. 2 Controller and hydraulic actuator 

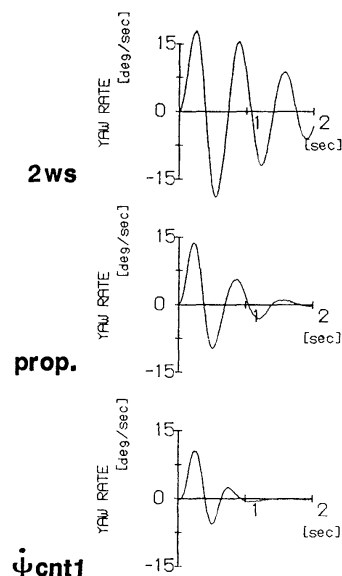

$\dot{\psi}$ cnt1

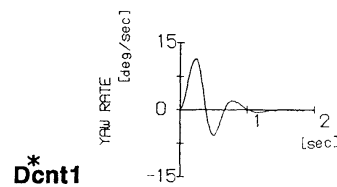

Dent1

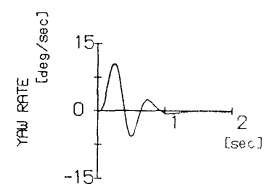

Fig. 6 Free response at $150 \mathrm{~km} / \mathrm{h}$ (proving ground test)
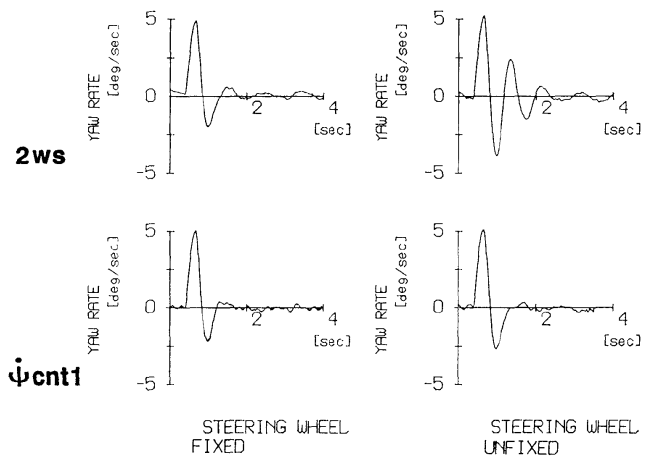

Fig. 7 Crosswind stability test at $180 \mathrm{~km} / \mathrm{h}$ (proving ground test)

操舵車と前輪操舵車との「横風安定性試験」の結果を 示す. 条件は車速 $180 \mathrm{~km} / \mathrm{h}$, 横風帯の幅 $12 \mathrm{~m}$, 風速 $22.5 \mathrm{~m} / \mathrm{s}$ である.

操舵角を固定すると後輪は操舵されないので，四輪 操舵車は前輪操舵車と同じ運動をする. しかしステア リングハンドルから手を放し, 自動車の入力を操舵卜 ルクとすると, 四輪操舵のほうが横風を受けた場合の 収れん性が大幅に向上していることがわかる．操舵角 に対しフィードフォワード補償のみで後輪を操舵する
各方式は, 自動車の横風外乱に対する安定性を改善す るといえる.

またててでは示さないが， $\dot{\phi} \mathrm{cnt} 2, D^{*} \mathrm{cnt} 2, \alpha \mathrm{cnt} 2$ についても「舵手放し安定性試験」で良好な収束性が 確認されている ${ }^{122}$.

\section{5. まと め}

本論文では，操舵トルクを操舵入力とした四輪操舵 車のモデルをつくり, フィードフォワード補償のみで 後輪を操舵する 4 種類の制御則について, 極配置の計 算と計算機シミュレーションを行い，さらにてれらの 制御則を組み入れた四輪操舵車を試作して車両実験を 実施した。その結果つぎのととが明らかになった。

(1) 操舵トルクを操舵入力とすると, ヨーレート や横速度などの状態量が操舵角にフィードバックされ るので, 操舵角入力に対し設計されたフィードフォワ 一ド方式の四輪操舵制御系は自動車の極配置を変え, 自動車を安定化し，外乱に対する収束性を改善する.

（2）車両実験の結果と, 計算機シミュレーション の結果とは比較的よく一致し, 操舵トルク入力系とし てみた自動車の平面運動を 2 次，ステアリング系を 2 次とした, 簡単な近似モデルで安定性の解析が可能で ある.

（3）筆者らの提案した後輪を動的に操舵する方式 は，前輪操舵車と同じ定常ヨーレートゲインをもちな がら，安定性を向上させることができる．また比例制 御と同じ定常ヨーレートゲインとした場合す，比例制 御より安定性への寄与度は大きい.

また，本研究で用いた四輪操舵車の車両実験を実施 したドライバは，突風など外乱を受けてあ運転がしや すいととをコメントしており，自動車は操舵角だけで なく操舵トルクによって操舵されているすのと考えら れる. 本論文では自動車固有の安定性について論じた が，今後人間-自動車系としての安定性を考察してい きたい.

\section{参 考 文 献}

1) S. Sano, Y. Furukawa and S. Shiraishi: Four Wheel Steering System with Rear Wheel Steer Angle Controlled as a Function of Steering Angle, SAE Technical Paper Series, 860625 (1986)

2) 田中, 中本: マツダ車速感応型四輪操舵, 自動車技術会, $4 \mathrm{WS}$ シンポジゥム, June (1987)

3) Y. Fukunaga, N. Irie, J. Kuroki and F. Sugasawa: Improved Handling and Stability Using Four-Wheel Steering, The 11th Int. Conf. on Experimental Technical Safety Vehicles, Washington D.C., U.S. A., May 12-15 (1987)

4) 中谷, 小口: 四輪操舵車の特性とその将来, 自動車技術, $39-1,58 / 65$ (1985)

5）伊藤，藤代，川辺，金井，越智：四輪操舵車の新しい制 
御法, 計測自動制御学会論文集, 23-8, 828/834 (1987)

6) 永井, 橋ケ谷: 仮想モデルフォロイング制御による四 輪操舵車の性能解析, 第 29 回自動制御連合講演会前刷, $517 / 518$ (1986)

7) 井口雅一：四輪操舵車の前・後輪協調制御方式に関する 理論的研究, 自動車技術会学術講演会前刷集, No. 861 , 159/164 (1986)

8) 林, 福井, 天野: 特性根による人間-四輪操舵車系の解 析，自動車技術会論文集，No. 36，167/173 (1987)

9) M.C. Good: Effects of Free-Control Variable on Automobile Handling, Vehicle System Dynamics,
$8-4,253 / 285$ (1979)

10）入江, 芝端：アクティヴ制御による操綎安定性の向上, 自動車技術，40-3，360/369（1986）

11) K. Ito, T. Fujishiro, K. Kanai and Y. Ochi: Four Wheel Steering System Synthesized by Model Maching Control, IEE-IMechE 6th Int. Conf. on Automotive Electronics No. 280, 237/241, London (1987)

12）藤代，伊藤，金井，越智：モデル追従と四輪操舵車, 自 動車技術，42-3，304/310（1988） 